\title{
Denis Marleau, da presença virtual à presença real
}

Marta Isaacsson

Desde a metade dos anos oitenta, o teatro do Québec vem despertando interesse internacional não só por seu crescimento, mas também por sua inquietação artística, uma sadia insatisfação que o impulsiona a romper com modelos tradicionais de representação e a abrir espaços a novas experimentações. No Brasil, entretanto, o conhecimento do que se realiza naquela região francófona do Canadá é ainda bastante restrito. Foi no sentido de aprofundar um pouco mais o conhecimento, que nos últimos tempos desviei meu olhar de pesquisa para esta região do continente norte-americano e aqui compartilho um pouco das experiências artísticas de Denis Marleau encenador, pedagogo e, atualmente, diretor artístico do Teatro Nacional de Ottawa.

Cabe inicialmente dizer que, a partir de 1975, a estrutura institucional do teatro do Québec se amplia e se diversifica através do surgimento de inúmeras Associações, organismos de defesa dos interesses de diferentes profissionais da atividade artística. Promove-se assim o fortalecimento social da atividade teatral, o que permite a multiplicação de pesquisas de linguagem. As novas experimentações começam então alterar o perfil do fazer teatral iniciado nos anos sessenta. O movimento de criação coletiva cede lugar a uma nova prática que vem romper com os modelos convencionais de representação da realidade. Trata-se agora de explorar formas de expressão capazes de surpreender a percepção do espectador e revelar o lado obscuro da realidade. Para tal, este "teatro de criação" estreita sua relação com as outras artes e começa a povoar a cena de criações híbridas, de obras fortemente caracterizadas pela mestiçagem, correspondendo em muito às peculiaridades do teatro pós-dramático, conforme conceito desenvolvido pelo crítico alemão Hans-Tiens Lehmann.1

Dentro deste contexto, ao lado de Robert Lepage (Ex-Machine) e Gilles Maheu (Carbone 14), Denis Marleau se impôs como um dos mais importantes diretores canadenses. Em 1982, fortemente marcado pelo trabalho de Strelher, Vitez e Kantor, Denis Marleau funda o Ubu Companhia de Teatro com a produção de Cœur à gaz et autres textes DADA, resultado de uma colagem de textos de Breton, Picabia, Schwitters e Tzara. O forte interesse pela literatura se revela nas mais de trinta produções artísticas, onde se destacam, entre outros autores, Alfred Jarry, Samuel Beckett, Vladimir Vladimirovitch Maïakovski, BernardMarie Koltès, Georg Büchner e Thomas Bernhard. Algumas vezes, Marleau se viu acusado de infidelidade à literatura quebequense, em uma província imbuída pela defesa de uma identidade diferenciada do restante do país. Aos seus detratores, ele responde sublinhando a importância do interculturalismo e afirmando encenar de maneira quebequense. 
É no texto que Denis Marleau busca o motor de uma criação lúdica e poética, desvendando a musicalidade da palavra, o ritmo da frase. A importância atribuída à palavra, não impede, todavia, Marleau de fazer da cena um espaço de diálogo multidisciplinar, integrando linguagens plásticas, coreográficas, musicais. Nesse processo transversal com outras linguagens, em 1996, ao adaptar para cena Os Três Últimos Dias de Fernando Pessoa de Antonio Tabucchi, lança mão pela primeira vez do uso do vídeo. A indiscutível genialidade de Marleau é de integrar o vídeo a serviço da composição do personagem. É assim que um único ator interpreta Pessoa e seus diferentes heterônimos, em difícil exercício de atuação, onde a contracenação deve se adequar ao contato com a imagem e som previamente registrados.

A experiência será aprofundada na criação de Os Cegos de Maurice Maeterlinck ${ }^{2}$ apresentada em 2002 no Museu de Arte Contemporânea de Montreal e anunciada como "fantasmagoria tecnológica". Ali Marleau encontrou no recurso do vídeo um caminho para desvendar a figura do duplo, da vida e da morte, da presença e da ausência, que parece assombrar o UBU Companhia de Teatro, como fazia com Cricot 2 de Tadeusz Kantor. Em sua abordagem do texto de Maeterlinck, Marleau multiplica seis vezes os rostos de cada um de seus dois atores, Céline Bonnier e Paul Savoie, através de registros em vídeo. Projetadas sobre máscaras em cera, as imagens compõem a ilusão de doze pessoas imóveis, separadas, em uma floresta escura, que ignorando a saída, falam sem cruzar o olhar, para suportar a angústia. Ao distribuir todas as palavras de Maeterlinck a duas únicas vozes, de um homem e uma mulher, Marleau coloca o espectador diante talvez do último casal representante da humanidade. Um casal que parece ter somente na voz a derradeira força de expressão, pois muito pouco seus rostos comunicam. E é assim também que Marleau demonstra que o "teatro de imagem" e o "teatro de texto" não são duas vias distintas e irreconciliáveis.

Nesta experiência de Os Cegos, Denis Marleau já contava com a preciosa colaboração de Stéphanie Jasmin. Com formação em História da Arte (École du Louvre -Paris) e em Cinema (Université de Concórdia - Montréal), Stéphanie assessora a dramaturgia e a concepção artística das produções do Ubu Companhia de Teatro desde 2001, ${ }^{3}$ além de atuar como dramaturga junto às coreógrafas Ginette Laurin et Estelle Clareton e de realizar suas criações independentes. ${ }^{4}$

Paralelamente as suas atividades de criação, Denis Marleau dirige ateliês em diferentes instituições, e tem sido convidado a realizar estágios na França, Bélgica e Itália. Foi no contexto de um desses estágios internacionais que Marleau retornou à questão da presença do ator, mais uma vez motivado por Maeterlinck, como nos relata, no texto abaixo, Stephanie Jasmin. A presença do ator que em Os Cegos se reforçava, dialeticamente, por sua ausência, aparece aqui abordada de maneira diferente, ou nem tanto. 


\section{Notas}

${ }^{1}$ Hans-Thies LEHMANN,. Le theatre postdramatique. Paris: L'Arche, 2002.

${ }^{2}$ Maurice Maeterlincki (Bélgica, 1862-1949).

${ }^{3}$ Entre as produções que contaram com a participação de Stephanie Jasmin, ressalta-se Intérior e Os Cegos de Maeterlinck; Dorme minha pequena criança de Jon Fosse e Comédia, de Samuel Beckett, bem como a realização dos vídeos O Coração da Rosa de Pierre Perrault e Monge Negro, de Anton Tchekhov.

${ }^{4}$ Em junho de 2005, Stephanie Jasmin realizou a encenação de seu texto Ombres no Espace Libre. 